\title{
RECORDED CHANGES IN SOME BIOCHEMICAL INDICATORS OF GRASSCARP CTENOPHARYNGODON IDELLA EXPOSED TO MERCURY AND ZINC
}

\author{
Magdy A. Salah El-Deen ${ }^{1}$, Reda E. Saleh", Tay E. Abd El- \\ Razik ${ }^{3}$ and El Saiad K. Abo-Hegab ${ }^{3}$
}

1. National Water Research Center,Adm. Building, El-Kanater, Egypt.

2. Analytical Microtechnique Unit, Cairo University, Egypt.

3. Zoology Department, Faculty of Science, Cairo University, Egypt.

Key words: Grass carp,mercury, zinc, aematocrit, haemoglobin, osmolality, acetylcholinesterase,sodium, potassium, water content.

\section{ABSTRACT}

Grass carp Ctenopharyngodon idella, fingerlings were exposed to lethal and sublethal concentrations of mercury and zinc. The changes in haemoglobin $(\mathrm{Hb})$ haematocrit $(\mathrm{Ht})$, osmolality, branchial $\mathrm{Na}^{+}-\mathrm{K}^{+}$-ATPase, acetylcholinesterase (AchE), sodium $\left(\mathrm{Na}^{+}\right)$, potassium $\left(\mathrm{K}^{+}\right)$and water content were recorded. Blood $\mathrm{Hb}$ and $\mathrm{Ht}$ showed a general trend of significant decrease in fish exposed to lethal and sublethal concentrations of mercury and zinc. The serum osmolality showed a significant increase on exposure of fish to lethal and sublethal concentrations of mercury and zinc. In fishes exposed to lethal concentration of mercury and sublethal concentration of mercury and zinc, the activity of branchial $\mathrm{Na}^{+}-\mathrm{K}^{+}$-ATPase was increased, while in case of lethal exposure to zinc, the enzyme activity was reduced. Serum AchE activity decreased in fish exposed to lethal concentration of mercury and sublethal concentration of zinc. On the other hand, the enzymatic activity was increased in fishes exposed to lethal concentration of zinc and sublethal concentration of mercury. In case of brain, the AchE activity increased in fishes exposed to lethal concentration of mercury and zinc and decreased in fishes exposed to sublethal concentration of mercury and zinc. The concentrations of $\left(\mathrm{Na}^{+}, \mathrm{K}^{+}\right)$in serum, liver and muscle were significantly increased when fish were exposed to either lethal or sublethal treatments. The water content of liver 
and muscle increased generally, on exposure to lethal and sublethal concentrations of mercury and zinc.

\section{INTRODUCTION}

Pollution of aquatic habitats is an inevitable problem aquaculturists face. The intrusion of heavy metals and their salts in aquatic environment and their accumulation in biotic system induced several structural and functional alterations in the biota (Abel, 1998).

Many workers have attempted to identify certain biochemical and physiological parameters as indices of pollutants stress on aquatic animals (Heath, $1987 \&$ Sorensen, 1991). The value of biochemical indices of stress lies in the fact that they may be early warning signs, signaling a possible detrimental effect prior to whole scale changes in population and community structure and function potential risks to human health from $(\mathrm{Hg})$ accumulated in fish and other aquatic organisms has been a major concern since the massive poisoning following methyl mercury discharged into Menameta Bay, Japan in the 1950s. More concerns have arisen about the impact of $\mathrm{Hg}$ on health of indigenous people who rely on fish as a dietary staple in areas including the Amazon basin (Barbosa et al., 1995 and Fleming et $a l ., 1995)$. Mercury has neurotoxic and teratogenic effects. Many studies involved exposing fish to high level of inorganic mercury $(\mathrm{Hg})$ or methyl mercury $(\mathrm{Me} \mathrm{Hg}$ ), caused severe gill damage (Paulose, 1987) and interfered with physiological processes involving the gill, including gas exchange and ion regulation (Lock et al., 1981; Stinson and Mallat, 1989).

Zinc is a potential toxicant to fish with water hardness and $\mathrm{pH}$ constituting the principal modifying factors of zinc toxicity (Everall et al., 1989). Major toxic effects of elevated concentrations of water borne $\mathrm{Zn}$ are disturbances of acid-base and ion regulation (e.g. impairment of the branchial uptake of $\mathrm{Ca}^{2+}$ ) disruption of gill tissue and hypoxia (Hogstrand et al., 1994). Chronically, toxic concentrations do not affect the gills, but cause general enfeeblement and extensive deterioration of the liver, kidneys, heart, skeletal muscles, gonads and spleen (Holcombe et al., 1979). 
The objective of the present work was to study and evaluate some physiological and biochemical changes in the grass carp in relation to lethal and sublethal exposure to mercury and zinc.

\section{MATERIAL AND METHODS}

Experimental animal and design:

Grass carp fingerlings samples with average weight 20 $\pm 2.0 \mathrm{~g}$ used in the present work were abtained from Delta Breeding Station (DBS), Cairo. Fish were acclimated to laboratory conditions for 2 weeks before experimental work. Mercuric chloride $\left(\mathrm{HgCl}_{2}\right)$ and zinc chloride $\left(\mathrm{ZnCl}_{2}\right)$, the toxicants were obtained from Merck Company (Reagent grade) and were mixed into solutions to provide the required concentrations.

\section{Groups of Fish:}

Ten fish per group were exposed to the 96-hLC50 0.62 $\mathrm{mg} \mathrm{Hg}++1$ or $11.46 \mathrm{mg} \mathrm{Zn}+4 /$, lethal exposure) determined according to Salah El-Deen et al. (1996) and scarificed after 3, 6, $12,24,48$ and 96 hours of exposure. Other groups were exposed to $1 / 10$ of the $96-\mathrm{hLC}_{50}\left(0.062 \mathrm{mg} \mathrm{Hg}^{2+} /\right.$ or $1.146 \mathrm{mg} \mathrm{Zn}^{2+} / \mathrm{l}$, sublethal exposure) and sacrificed after $1,2,4,8,16,32$ and 64 days of exposure. Control groups with no toxicant were also included in both experiments.

\section{Analytical Techniques:}

Eight fish from each group at every interval time after exposure were randomly selected and anesthetized in $120 \mathrm{mg} / \mathrm{l}$ tricaine methane sulfonate (MS222) solution. Blood was obtained by direct puncture of the heart using glass micropipette. Serum was collected by centrifugation $(8000 \mathrm{rpm})$ and was stored in a deep freezer $\left(-20^{\circ} \mathrm{C}\right)$ for further analysis. After decapitation of fish, piece of white epaxial muscle and liver were taken for further biochemical studies. Haemoglobin content ( $\mathrm{Hb})$ was estimated using cyanmethemoglobin method (Van Kampen and Zijlstra, 1961). Haematocrit percentage (Ht) was determined according to Britton (1963).

Serum osmolality was measured with freezing point depression osmometer. The branchial $\mathrm{Na}^{+}-\mathrm{K}^{+}-\mathrm{ATPase}$ activity 
was measured at $37^{\circ} \mathrm{C}$ and calculated as the differences between the rate of inorganic phosphate liberated in the present and absence of ouabain (Johanson et al., 1977). The released inorganic phosphorous was measured by the method of Fiske and Subbarow (1925). The serum and brain AchE activities were estimated the calorimetric method according to Ellman et al. (1961) using Boheringer Mannheium Kit.

Sodium and potassium concentrations in serum, muscle and liver were determined according to Loenn and Ockari (1982) and measured with a flame photometer (Corning 410). Muscle and liver water contents were determined through difference between fresh and dry tissue weights.

\section{Statistical Analysis:}

The results were expressed as mean \pm S.E.M. Data were statistically analyzed using analysis of Variance and NewmanKelus test to evaluate the comparisons between means at $\mathrm{P}<0.05$ (Steel and Torrie, 1980).

\section{RESULTS}

Blood $\mathrm{Hb}$ in the grass carp exposed to lethal and sublethal concentration of mercury and zinc (Table 1), showed a significant decrease $(\mathrm{P}<0.05)$. On lethal exposure to mercury, the minimum concentration $(3.58 \pm 0.87 \mathrm{~g} / \mathrm{dl})$ was recorded after 96 hours of exposure. The same was observed in case of lethal exposure to zinc, the lowest value $(3.37 \pm 0.29 \mathrm{~g} / \mathrm{dl})$ was recorded after 96 hours. On sublethal exposure to mercury, the lowest concentration $(3.09 \pm 0.26 \mathrm{~g} / \mathrm{dl})$ was recorded after 32 days, also a significant decrease in $\mathrm{Hb}$ concentration was recorded. On sublethal zinc exposure, the minimum value $(2.81 \pm 0.23 \mathrm{~g} / / \mathrm{dl})$ was recorded after 64 days of exposure.

In Table (1), the blood $\mathrm{Ht} \%$ in fish exposed to lethal concentration of $\mathrm{Hg}$ exhibited a significant decrease and the lowest value was (23.46 $\pm 1.97 \%)$ after 96 hours of exposure. The same was observed in case of lethal zinc exposure and the minimum (\%) was (20.40 $\pm 1.89 \%)$ after 96 hours of exposure. The same pattern of response was observed in sublethal exposure to mercury and zinc, the corresponding values were $[1723 \pm 1.56$ $(\mathrm{Hg})$ and $15.70 \pm 1.15(\mathrm{Zn}) \%]$ after 32 and 64 days, respectively. 
As shown in Table (2), the serum osmolality of fish exposed to lethal concentration of mercury and zinc exhibited a significant increase and the maximum recorded levels were [343.50 $\pm 5.94(\mathrm{Hg})$ and $360.43 \pm 7.07(\mathrm{Zn})$ mosm] after 96 hours in both experiments. Also sublethal exposure exhibited a significant increase in serum osmolality and the highest recorded levels were $[366.95 \pm 7.41(\mathrm{Hg})$ and $385.65 \pm 3.92(\mathrm{Zn})$ mosm] after 32 and 64 days of exposure, respectively.

In Table (3), fish exposed to lethal concentration of mercury and sublethal concentration of mercury and zinc exhibited elevation in the activity of branchial $\mathrm{Na}+-\mathrm{K}+-\mathrm{ATPase}$, the corresponding activities were $(4.21 \pm 0.05,3.90 \pm 0.14$ and $4.28 \pm 0.05 \mu \mathrm{mol} / \mathrm{Pi} / \mathrm{mg}$ protein $/ \mathrm{hr}$ ) after 96 hours, 32 and 64 days of exposure, respectively. In case of lethal exposure to zinc, a non significant decrease $(P>0.05)$ was observed in the enzyme activity.

Serum AchE activity (Table 4) decreased in fishes exposed to lethal concentration of mercury and sublethal concentration of zinc. Also, the brain AchE was decreased in fishes exposed to sublethal concentration of mercury and zinc. On the other hand, the serum enzymatic activity was increased in fishes exposed to lethal concentration of zinc and sublethal concentration of mercury and also increased in brain of fishes exposed to lethal concentrations of mercury and zinc.

The concentration of $\mathrm{Na}+$ in serum, liver and muscle of the grass carp exposed to either lethal or sublethal concentration of mercury and zinc (Table 5) showed a general trend of significant increase $(P<0.05)$ compared to the control values. Regarding $\mathrm{K}+$ concentration, it showed a general pattern of significant increase in serum, liver and muscle after lethal and sublethal exposure to mercury and zinc (Table 6).

The water content of liver and muscle of grass carp, increased significantly on exposure to lethal and sublethal concentration of mercury and zinc as shown in Table (7).

\section{DISCUSSION}

Physiological and haematological measurements have been used as indicators of the state of fish health condition and as a biochemical method for assessing the possible mode of action 
of stressors (Heath, 1987 \& Adams, 1990). The changes in Ht and $\mathrm{Hb}$ values in fish exposed to different environmental stressors and as a result of chemical treatment have been reported by Salah El-Deen (1991) when exposed Ctenopharyngodon idella to diquat; and Allen (1994) in case of Oreochromis aureus exposed to mercury.

Mazher et al. (1987), studied the effects of exposure of the Nile catfish Clarias lazera, to sublethal concentration of mercury $(0.4,0.6,0.8$ and $1.0 \mathrm{mg} \mathrm{Hg} / \mathrm{l}$ ) and found a progressive fall in $\mathrm{Hb}$ content and $\mathrm{Ht}$ value, and an increase in WBCs count. The authers attributed such decrease to the reduction of $\mathrm{RBCs}$ production in the bone marrow under the action of mercury poisoning as well as to intrahepatic and intrasplenic haemorrhage.

Panigrahi and Misra (1980) exposed Tilapia mossambica to a sublethal concentration of $0.5 \mathrm{mg} / \mathrm{l}$ as mercuric nitrate $[\mathrm{Hg}$ $\left(\mathrm{NO}_{3}\right)_{2}$ ] and found that there was a decrease in $\mathrm{Hb}$ content and $\mathrm{Ht}$ value as a result of haemolysis and vaculization of RBCs caused by mercury. In addition, Goel and Gupta (1985) reported a decrease in $\mathrm{RBCs}$ count; $\mathrm{Hb}$ content and $\mathrm{Ht}$ value of Heteropneustes fossilis in response to environmental exposure to zinc for 30 days. The observed decrease in red cell indices reflects a severe anemic state closely related to prolonged zinc exposure.

Abo-Hegab et al. (1989) pointed out that the Hb level in grass carp, Ctenopharyngodon idella exposed to urea decreased throughout the experiment. They owed such decrease to disturbances of the osmotic pressure inside and outside the cells due to gain of water in the extracellular fluid.

In the present study, Ctenopharyngodon idella was exposed to lethal and sublethal concentrations, of mercury and zinc showed a significant decrease in $\mathrm{Hb}$ content and $\mathrm{Ht}$ values. This decrease could be attributed to many features such as impairment of gas exchange by the gills, disequilibrium of the osmotic pressure, haemolysis of erythrocytes and/or dysfunction of the spleen and destruction of large number of erythrocytes. An alternative explanation of the reduction of $\mathrm{Hb}$ and $\mathrm{Ht}$ is the shrinkage of RBCs, and/or reduction in RBCs production in the haematopoietic organs under the action of heavy metal 
Recorded changes in some biochemical indicators of 63

grass carp Ctenopharyngodon idella exposed to mercury and zinc

concentrations as reported by Kumari and Banerjee (1993) and Abbas (1998).

Changes in plasma osmolality have long been considered as an indicator of stress. In fresh water fishes, an increase in osmolality is supposed to indicate stress (Heath, 1987). If the concentration of heavy metal in the water is high enough, there is supposed to be a disruptive influence on the structural organization of the gill tissue. This will influence osmotic and ionic regulation in fish (Allen, 1993).

Stagg et al. (1992) reported that plasma osmolality and chloride concentrations are considered as an indicator of gross osmoregulatory dysfunction. Changes in plasma solute concentrations will be determined not just by the ability of the fish to maintain osmoregulatory homeostasis but also by the osmotic and ionic gradients imposed on the fish by the changes in environmental stressors.

In addition, Stagg et al. (1992) showed that flounder, Platichthys flesus at Port Edgar had higher mercury levels and a higher plasma osmolality than those from Eden. This strongly suggests that the inhibitory effects of contaminants, such as mercury, present at Port Edgar may cause osmoregulatory dysfunction in flounder at this site.

In the present study, lethal and sublethal concentrations of mercury and zinc caused a significant elevation in serum osmolality. These changes could be attributed to either loss of serum water or/and increase of the internal inorganic and organic osmolytes, as a result of osmoregulatory dysfunction caused by the toxicant. This assumption is supported by the results of Stagg et al. (1992).

Branchial $\mathrm{Na}^{+}, \mathrm{K}^{+}$ATPase is a key enzyme in fish osmoregulation being central to the transport of monovalent ions in the gills of both marine and fresh water teleost (Evans, 1987). The enzyme has been shown to be sensitive to a wide range of contaminants following acute and chronic exposure.

Sastry and Sharma (1980) had reported that $\mathrm{Na}^{+}, \mathrm{K}^{+}$ activated adenosine triphosphatase elevated by the acute exposure to mercuric chloride, while inhibited by the chronic exposure.

Kozik et al. (1977) observed a decrease in adenosine 
triphosphatase activity in the wall of capillaries of cerebral cortex and assumed that the phenomenon may be indicative of an injury to the blood-brain barrier. Similarly, Chang and Hartmann (1972) observed injury to the endothelium of the capillaries as well as to the surrounding galial membrane after mercuric chloride intoxication.

In the present investigation, the branchial $\mathrm{Na}^{+}, \mathrm{K}^{+}$ATPase activity, in the grass carp showed a non significant alteration after lethal zinc exposure. On the contrary, $\mathrm{Na}^{+}, \mathrm{K}^{+}$ATPase in the gills of the grass carp is clearly inhibited by the lethal and sublethal exposure to mercury and sublethal exposure to zinc intoxication. The reduction in $\mathrm{Na}^{+}, \mathrm{K}^{+}$-ATPase activity observed in the present study may be due to an increased demand for energy supply in the gill as ATPase breakdown ATP and liberates energy. This assumption is highly supported by the work of Lock et al. (1981) and Jagoe et al. (1996).

The mechanism of osmoregulatory disruption and alteration of $\mathrm{Na}^{+}$and $\mathrm{K}^{+}$concentrations have been studied by a number of investigators (Eddy, 1982 and Heath, 1987). Christensen et al. (1977), reported an increase in plasma $\mathrm{Na}^{+}$ concentration of brook trout after being exposed to lead nitrate and methyl mercury chloride at different concentrations for 2 and 8 weeks. Methyl mercury injected into flounders, Pesudopleuromectes americanus; on a daily basis for 13 days caused accumulation of mercury in the gills up to $24 \mathrm{ppm}$, but this treatment showed no effect on either intracellular or extracellular electrolytes (Schmidt - Nielsen et al., 1977). Bukley et al. (1979) observed an increase in plasma $\mathrm{K}^{+}$concentrations of Coho salmon, after being exposed to different concentration of ammonia for 91 days. Exposure of sheephead in sea water to a massive dose of copper (exceeding the 48-hLC $\mathrm{C}_{50}$ ) was accompanied by a large increase in all plasma electrolytes (Cardeilhac et al., 1979). The latter authers suggested that the greatly elevated plasma potassium concentration might be the cause of death as a result of exposure to copper in sea water.

In normally functioning kidneys, sodium and potassium ions are reabsorbed from the glomerular filtrate and passes through the kidney tubules (Smith et al., 1976). Since, heavy metals are known to damage renal tubules and induce renal 
failure (Rojik et al., 1983), the increased levels of sodium and potassium might be due to the renal dysfunction (Larrson, et al., 1985).

Tulasi et al. (1990) reported a severe alteration and disturbance in the ionic balance in Barytelphusa guerini exposed to lead nitrate and lead acetate. The author attributed these changes to the alteration in the active transport of ions. Moreover, Haux and Larrson (1982) attributed the ionic disturbance to the outward leakage of intercellular ions, especially potassium, caused by lead ions toxications.

In the present study, grass carp exposed to lethal and sublethal concentration of mercury and zinc exhibited a gradual increase in $\mathrm{Na}^{+}$and $\mathrm{K}^{+}$ions in serum, liver and muscle. This increase could be considered as a result of electrolyte balance disturbance and may be attributed to the outward leakage of intercellular ions and/or to renal failure caused by accumulation of mercury and zinc in kidney, which may contribute to increasing in the $\mathrm{Na}^{+}$and $\mathrm{K}^{+}$as postulated by Zaghloul (1997) and Abbas (1998).

The activity of acetylcholinesterase, an enzyme that modulates the amount of the neurotransmitter substance (acetylcholine) at the nerve cell junction, was reported to vary in different organs in response to different environmental stressors (Coppage, 1971 and Adams, 1990). Pham and Plancade (1971) found that, after acute cadmium intoxication, the activity of brain AchE was increased, while chronic exposure did significantly change the enzyme activity. Tejendra et al. (1991), observed increase in brain AchE activity of rosy barb, Barbus conchonius exposed to $12.6 \mathrm{mg} / \mathrm{L}$ cadmium chloride. A similar increase in brain AchE activity was found in the sheephead minnow, Ciprinodon variegatus exposed to lower concentration of organophosphorous insecticide diazinon (Goodman et al., 1979). Such increase of the enzyme activity was attributed by the authers to represent the alarm reaction to the presence of the pollutants and can be interpreted as an influence of the stressors on cholinergic function. On the other hand, mercuric chloride was found to produce inhibition in AchE activity in brain and spinal cord of rats (Kozik et al., 1977). Olson and Christersen (1980) reported that the in vitro effect of $\mathrm{Cd}$ in the rosy barb resemble 
those described in the fathead minnow, Pimephales promelas which also showed AchE inhibition in presence of $\mathrm{Cd}, \mathrm{Hg}, \mathrm{Cu}$ and $\mathrm{Pb}$. These effects seem to be due to inhibition of $\mathrm{Ca}^{2+}$ function atipresynaptic nerve terminals (Tejendra et al., 1991).

In the present investigation, the AchE activity in grass carp exposed to lethal and sublethal concentrations of mercury and zinc: showed different patterns of responses (biphasic response), while there was a general increase in AchE in brain exposed to lethal concentration of zinc, there was an inhibition in serum enzyme exposed to lethal concentration of mercury. On the other hand: inhibition of AchE activity in serum (exposed to lethal zinciconcentration) and in brain (exposed to lethal mercury and zinc concentrations) was observed. In addition, there was an increase: in AchE activity in serum exposed to sublethal concentration of mercury.

The increase in the AchE activity could be attributed to the alarm resction to the presence of mercury or zinc and during which more nerve impulses transfer may be needed (Hanke et al., 1983 and Assem, 1985). However, the decrease in AchE activity could be due to the binding of mercury or zinc ions to lipid - rich structural component of mitochondria and subsequently affect the activities of the enzymes like AchE which associate directly with lipid-rich fractions, specially where integrity of the structural components is necessary for maximum catalytic activity. Furthermore, the decrease in AchE activity could be due to the decrease in synthesis of the enzyme by the inhibitory nature of toxicants, and also to asphyxiation. Such explanation is high supported by the work of Suresh et al. (1992) and Abu El-Ella (1996)

Water plays a vital role in the physiology and biochemistry of animals for maintaining $\mathrm{pH}$ and several others biochemical reactions. Zaghloul (1997) reported increase in liver and musclk water content in Oreochromis niloticus after exposure to mercury and zinc.

Moreover, Abbas (1998), reported increase in liver and muscle water content of Oreochromis aureus and Clarias gariepinas under the effect of lethal and sublethal exposure to copperiend lead: This elevation in liver and muscle water content is in-agrecment with-Wheatherly. and Gill (1987) who reported 
that, the depletion of muscle total protein (as observed in this study) result in tissue hydration and an inverse dynamic relationships between protein and water content in the liver and muscle. This assumption agrees with the results of the present investigation (increase liver and muscle water content after lethal and sublethal exposure to mercury and zinc) and might be attributed to reduction in metabolite activity under toxicant stress conditions as reported by Verma and Tonk (1983).

In conclusion, many workers have stressed the need for the establishment of normal physiological and hematological values in connection with pollution and its effect. However, the possibility to set a standard as a diagnostic tool is still not definitive.

\section{REFERENCES}

Abbas, H.H. (1998): Toxicological effects of copper and lead on some physiological aspects in two fish species, blue tilapia (Oreochromis aureus) and African catfish (Clarias gariepinus). Ph.D. Thesis, faculty of Science, Cairo University, Egypt.

Abel, P.D. (1998): Water Pollution Biology. Taylor and Francis Ltd. London.

Abo-Hegab, S.; Kandil, A. and Moharram, N. (1989): Studies on the effect of exposure of grass carp Ctenopharyngodon idella to several environment pollutants. Chariges in the blood haematocrit and haemoglobin level. Proc. Zool. Soc. A.R. Egypt, 17: 237-246.

Abu El-Ella, S.M. (1996): Studies on the toxicity and bioconcentration of cadmium on grass carp, Ctenopharyngodon idella. M.Sc. Thesis, Faculty of Science, Helwan University, Egypt.

Adams, S.M. (1990): Biological Indicators of Stress in Fish. American Fisheries Symposium 8, Bethesthda, Maryland, USA. 
Allen, P. (1993): Effects of Acute exposure to cadmium (II) chloride and lead (II) chloride on the Haematological profile of Oreochromis aureus (Steindachner). Comp. Biochem. Physiol., 105 C : 213-217.

Allen, P. (1994): Changes in the haematological profile of the cichlid Oreochromis aureus (Steindochner) during acute inorganic mercury intoxication. Comp. Biochem. Physiol., $108 \mathrm{C}$ (1): 117-121.

Assem, H. (1985): Effects of petroleum refinery waste water exposure on plasma cortisol and brain acetylcholinesterase in carps, Cyprinus carpio. 1. Changes induced by phenol. Proc. Zool. Soc. A.R.Egypt, 9:11-18.

Barbosa, A.C.; Boișchio, A.A.; East, G.A.; Ferrari, I.; Goncalves, A.; Silva, P.R.M. and da Cruz, T.M.E. (1995): Mercury contamination in the Brazilian Amazon Environmental and occupational aspects. Water Air Soil Pollut., 80: 109 - 121.

Britton, C.J. (1963): "Disorders of The Blood." $9^{\text {th }}$ edition. J. and A. Churchill, ed. LTD., London.

Bukley, J.A.; Whitmor, C.M.; Liming, B.D. (1979): Effects of prolonged exposure to ammonia on the blood and liver glycogen of coho salmon, Oncorhynchus kisutch. Comp. Biochem. Physiol., 63 C: 297-304.

Cardeilhac, P.T.; Simpson, C.F.; Lovelock, R.L.; Yosha, S.R.; Calder Wood, S.F. and Grudat, J.C. (1979): Failure of osmoregulation with apparent potassium intoxication in marine teleosts, a primary toxic effect of copper. Aquaculture, 17:231-237.

Casillas, E. and Smith, L.S. (1977): Effect of stress on blood coagulation and hematology in rainbow trout . Salmo gairdneri. J. Fish Biol., 10: 481 - 491.

Chang, L.W: and Hartmann, H.A. (1972): Ultrastructural studies of the nervous system after mercury intoxication. I. 
Recorded changes in some biochemical indicators of

Pathological changes in the nerve cell bodies. Acta Neuropathol., 20: 122 - 131 .

Christensen, G.M.; Hunt, E.P. and Fiandt, J. (1977): The effect of methyl mercuric chloride, cadmium chloride and lead nitrate on six biochemical factors of the brook trout, Salvenlinus fontinalis. Toxicol. Appl. Pharmacol., 42: $523-530$.

Coppage, D.L. (1971): Characterization of fish brain Acetylchlinesterase with automated $\mathrm{pH}$ state for inhibition studies. Bull. Environ. Contam. Toxicol. 6 : 304-310.

Eddy, F.B. (1982): Osmotic and ionic regulation in captive fish with particular reference to salmonids. Comp. Biochem. Physiol., 37 B: 125-141.

Ellman, G.L., Courtney, K.A.V. and Featherstone, R.M. (1961): A new and rapid coloremetric determination of acetylcholinesterase activity. Biochem. Pharmacol. 7: 88-95.

Evans, D.H. (1987): The fish gill: Site of action and model for toxic effects of environmental pollutants. Env. Health Perspect., $71: 54$ - 58.

Everall, N.C.; Mac Farlane, N.A.A. and Sedgwick, R.W. (1989): The interaction of water hardness and $\mathrm{pH}$ with the acute toxicity of zinc to the brown trout, Salmo trutta L. J. Fish Biol., 35: 27 - 36.

Fiske, C.H. and Subbarow, Y. (1925): The colorimetric determination of phosphorous. J. Biol. Chem., 66: $375-400$.

Fleming, L.E.; Watkins, S.; Kaderman, R.; Levin, B.; Ayyar, D.R.; Bizzio, M.; Stephens, D. and Bean, J.A. (1995): Mercury exposure in humans through food consumption in the Everglades of Florida. Water Air Soil Pollut., 80: 41-48. 
Goel, K.A. and Gupta, K.C. (1985): Haematobiochemical characteristics of Heteropneus's fossilis under the stress of zinc. Indian J. Fish., 32 (2):256-260.

Goodman, L.R.; Hansen, D.J.; Coppage, D.L.; Moore, J.E. and Matthews, E. (1979): Diazinon: Chronic activity to brain acetylcholinesterase inhibition, in the sheephead minnow, Cyprinodon variegatus. Trans. Am. Fish Soc., 108: 479- 488 .

Hanke, W.G.; Bubel, H. and Múller, R. (1983): Physiological changes in carps induced by pollution. Ecotoxicol. Environ. Safety, 7: 229-242.

Haux, C. and Larrson, A. (1982): Influence of inorganic lead on the biochemical blood composition in the Rainbow trout; Salmo gairdneri. Ecotoxicol. Environ. Safety, $6: 28-34$.

Heath (1987): Water Pollution and Fish Physiology. CRC. Press Inc. Boca Raton, Florida.

Hogstrand, C.; Wilson, R.W.; Polgar, D. ai' : Vood, C.M. (1994): Effects of zinc on the kinetics of branchial calcium uptake in fresh water rainbow trout during adaptation to water borne zinc. J. Exp. Biol., 186: $55-73$.

Holcombe, G.W.; Benoit, D.A. and Leonard, E.N. (1979): Long term effects of zinc exposure on brook trout (Salvelimus fontinalis). Trans. Am. Fisti. Soc., 108: 76-87.

Jagoe, C.H.; Shaw-Allen, P.L. and Brundage, S. (1996): Gill Na+$\mathrm{K}^{+}$ATPase activity in large mouth bass Micropterus salmoides from three reservoirs with different levels of mercury contamination. Aquat. Toxicol, 36: 161 176.

Johanson, S.L.; Ewing, R.D. and Lichatowich, J.A. (1977): Characterization of gill ( $\mathrm{Na}-\mathrm{K})$ activated adenosine triphosphate from chinook salmo, Oncorhynchus tshawytscha. JmExp. Biol. 299: $345-354$. 
Recorded changes in some biochemical indicators of 71

grass carp Cienopharyngadon idella exposed to mercury and zinc

Kozik, M.B.; Sosinski, E. and Szczech, J. (1977): Phosphatases and esterases activity in the brain following an acute sublimate intoxication. Folia Histochem. et Cytochem., 15: 18 - 23

Kumari, M. and Banerjee, V. (1993): Effect of lethal and sublethal levels of mercury on the blood of the fish Clarias batrachus. Environ. Ecol., II (2): 465 - 467.

Larrson, A.; Haux, C. and Sjobeck, M.L. (1985): Fish physiology and metal pollution: results and experiences from laboratory and field studies. Ecotoxicol. Environ. Safety, 9: $250-281$.

Lock, R.A.C.; Cruijsen, P.J.M. and Van-Overbeeke, A.P. (1981): Effects of mercuric chloride and methyl mercuric chloride on the osmoregulatory function of the gill in rainbow trout, Salmo gairdneri Richardson. Comp. Biochem. Physiol., 68 C: 151 - 159.

Loenn, B. and Ockari, A. (1982): Determination of muscle ions from trout, Salmo gairdneri, by a simple wet extraction technique. Comp. Biochem. Physiol., 72 A: $49-53$.

Mazhar, F.M.; Ashry, M.A. and Kadry, S.M. (1987): Effects of environmental pollution by mercury on blood parameters of the Nile catfish; Clarias lazera. Proc. Zool. Soc. A.R. Egypt., 13: 247 - 256.

Olson, D.L. and Christensen, G.M. (1980): Effects of water pollutants and other chemicals on fish acetylcholinesterase (in vitro).Environ.Res.,21: 327 335.

Panigrahi, A.K. and Misra, B.N. (1980): Toxicological effects of a sublethal concentration of inorganic mercury on the fresh water fish, Tilapia mossambica, Peters. Arch. Toxicol., 44: 269 - 278. 
Paulose, P.V. (1987): Accumulation of organic and inorganic mercury and histological changes in the gills of Gambusia affinis. Proc. Indian Nat. Sci. Acd., 53 B : 235 - 237.

Pham, H.C. and Plancade, Y. (1971): Etude comparee des effects $\mathrm{du}$ zinc et du cadmium surles activities cholinesterasiques tissulaires $\mathrm{du}$ " rat. Biochem. Pharmacol., 20: 729 - 736 .

Rojik, L.; Nemcsok, J. and Boross, L. (1983): Morphological and biochemical studies on liver, kidney and gill of fishes affected by pesticides. Acta Biol. Hung.34 (1): 81 92.

Salah, El-Deen, M.A. (1991): Physiological and biochemical changes in grass carp, Ctenopharyngodon idella, exposed to. diquat. Ph.D. Dissertation, Auburn University, Alabama, U.S.A.

Salah El-Deen, M.A.; Sharada, H.M.; Abu El-Ella, S.M. (1996): Some metabolic alteration in grass carp, Ctenopharyngodon idella induced by exposure to cadmium. J. Egypt Ger. Soc. Zool. 21 A: 441 - 457.

Sastry, K.V. and Sharma, K. (1980): Effects of mercuric chloride on the activities of brain enzymes in a fresh water teleost, Ophiocephalus (Channa) punctatus Arch. Environ. Contam. Toxicol. 9(4): 425-436.

Schmidt-Nielsen, B.; Sheline, J.; Miller, D.S. and Deldono, M. (1977): Effects of methyl mercury upon osmoregulation, cellular volume and ion regulation in winter flounder, Pesudopleuronectes americanus In: Physiological Responses of Marine Biota to Pollutants (Vernberg, F.J., Calabrese, A.; Thurberg, F.P. and Vemberg, W.B. eds.). Academic Press, New York.: 
Smith, P.; HejTmancik, E. and Camp, B. (1976): Acute effect of cadmium on Ictalurus punctatus (catfish). Bull. Environ. Contam. Toxicol., 15: 271 - 277.

Sorensen, E.M. (1991): Metal Poisoning in fish: Environmental and Life Sciences Associates. Autisn - Texas, CRC Press Inc., Boston, USA.

Stagg, R.M.; Rusin, J. and Brown, F. (1992): $\mathrm{Na}^{+}, \mathrm{K}^{+}$-ATPase activity in gills of the flounder (Platichthys flesus) in relation to mercury contamination. Mar. Environ. Res., 33: 255 - 266.

Steel, R.G.D. and Torrie, J.H. (1980): Principles and Procedures of Statistics $2^{\text {nd }}$ ed. Mc. Graw - Hill book Company. New York, USA.

Stinson, C.M. and Mallat, J. (1989): Branchial ion fluxes and toxicant extraction efficiency in lamprey (Petromyzon marinus) exposed to methyl mercury. Aquat. Toxicol., 15: 237 - 252.

Suresh, A.; Sivaramakrishan, B.; Victoriamma, P.C. and Radhakrishanaish, K. (1992): Comparative study on the inhibition of acetylcholinesterase activity in freshwater fish, Cyprinus carpio by mercury and zinc. Biochem. Inter., 26: $367-375$.

Tejendra, S.G.; Tewari, H. and Pande, J. (1991): In vivo and in vitro effects of cadmium on selected enzymes in different organs of fish Barbus conchonius (rosy barb). Comp. Biochem. Physiol., 100 C: 501 - 505.

Tulasi, S.J.; Yasmeen, R. and Rao, J.V. (1990): Ionic balance in the haemolymph of the freshwater carp, Barytelphusa guerini exposed to sublethal concentrations of lead acetate and lead nitrate. J. Environ. Biol., 11 (2):163168.

Van Kampen and Zijlstra, N.C. (1961): Determination of haemoglobin. Clin. Chem. Acta., 5: 719-720. 
Verma, S.R. and Tonk, I.P. (1983): Effect of sublethal concentration of mercury on the composition of liver, muscle and ovary of Notopterus notopterus. Water Air Soil Pollut., 20: 287 - 292.

Wheatherly, A.H. and Gill, H.S. (1987): Tissue and growth. Pages 147 - 173. In:Biology of Fish Growth. St. Edmunds Bury Press, Great Britain,

Zaghloul, K.H. (1997): Studies on the effect of water pollution along different sites of the River Nile on the survival and production of some fresh water fishes. Ph.D. Thesis, Faculty of Science, Cairo University, Egypt. 
Recorded changes in some biochemical indicators of

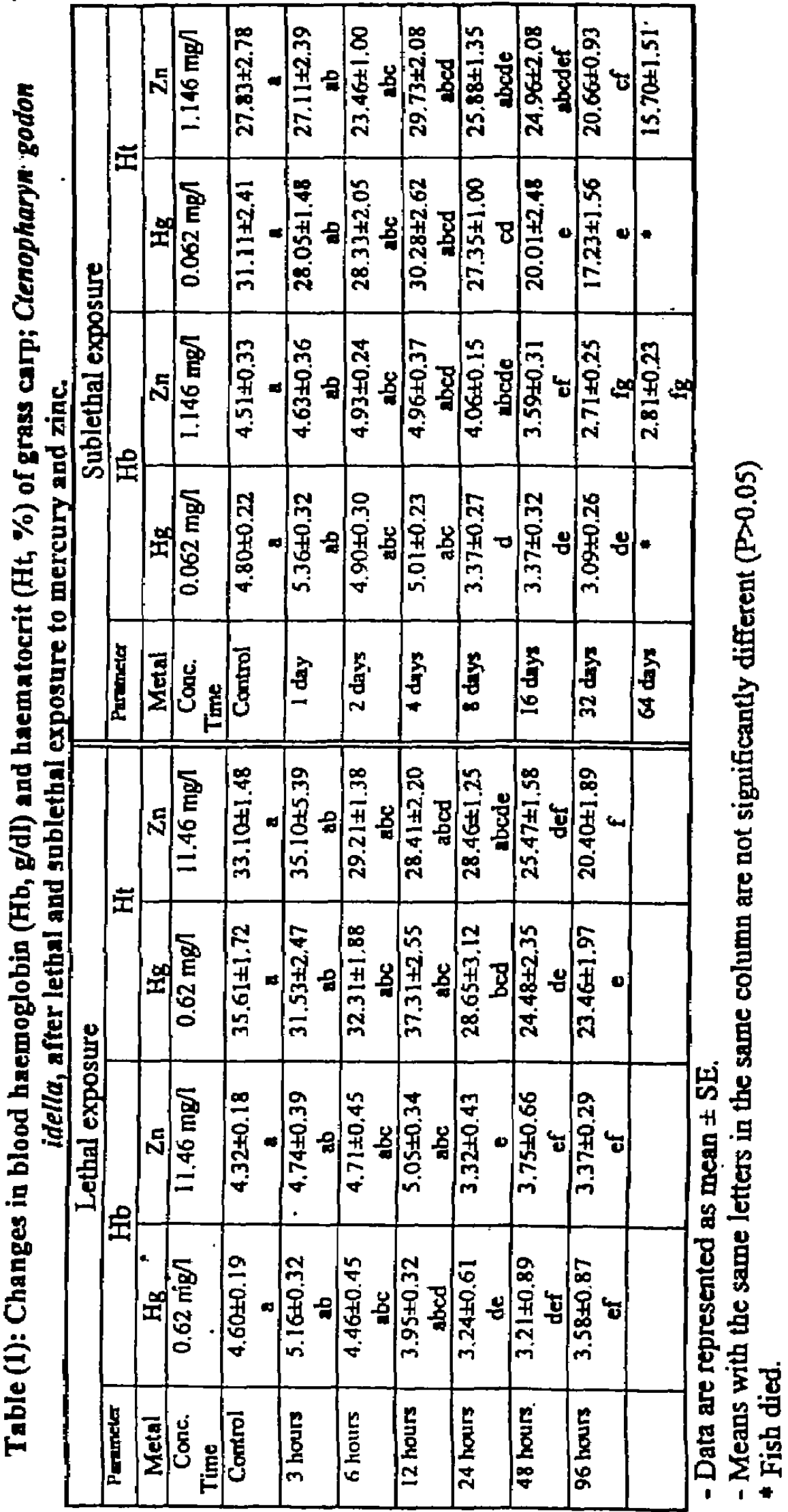


Table (2): Changes in serum osmolality (mosm) of grass carp; Crenopharyngodon idella, after lethal and sublethal exposure to mercury and zinc.

\begin{tabular}{|c|c|c|c|c|c|}
\hline \multicolumn{3}{|c|}{ Lethal exposure } & \multicolumn{3}{|c|}{ Sublethal exposure } \\
\hline Metal & $\mathrm{Hg}$ & $\mathrm{Zn}$ & Metal & $\mathrm{Hg}$ & $Z_{n}$ \\
\hline $\begin{array}{l}\text { Conc. } \\
\text { Time }\end{array}$ & $0.62 \mathrm{mg} / 1$ & $11.46 \mathrm{mg} / \mathrm{t}$ & $\begin{array}{l}\text { Conc. } \\
\text { Time }\end{array}$ & $0.062 \mathrm{mg} / 1$ & $1.146 \mathrm{mg} / \mathrm{h}$ \\
\hline Control & $248.00 \pm 5.39$ & $\begin{array}{c}243.03 \pm 4.28 \\
a \\
\end{array}$ & Control & $\begin{array}{c}240.30 \pm 4.6] \\
a\end{array}$ & $\begin{array}{c}241.88 \pm 4.96 \\
\mathrm{a}\end{array}$ \\
\hline 3 hours & $\begin{array}{c}286.66 \pm 8.27 \\
\mathrm{a}\end{array}$ & $\begin{array}{c}253.90 \pm 2.61 \\
\mathrm{ab}\end{array}$ & 1 day & $\begin{array}{c}248.10 \pm 7.25 \\
a\end{array}$ & $\begin{array}{c}241.2 \mathrm{j} \pm 3.36 \\
\mathrm{a}\end{array}$ \\
\hline 6 hours & $\begin{array}{c}316.68 \pm 5.86 \\
b\end{array}$ & $\begin{array}{c}255.75 \pm 4.20 \\
\text { abc }\end{array}$ & 2 days & $\begin{array}{c}260.95 \pm 8.15 \\
b\end{array}$ & $253.5 \pm 4.38$ \\
\hline 12 hours & $\begin{array}{c}329.41 \pm 10.69 \\
\text { be }\end{array}$ & $\begin{array}{c}237.06 \pm 3.78 \\
\text { abcd }\end{array}$ & 4 days & $\begin{array}{c}266.10 \pm 4.20 \\
b\end{array}$ & $270.33 \pm 4.58$ \\
\hline 24 hours & $\begin{array}{c}334.86 \pm 8.39 \\
\text { bed }\end{array}$ & $319.05 \pm 8.68$ & 8 days & $289.91 \pm 9.32$ & $283.76 \pm 4.12$ \\
\hline 48 hours & $\begin{array}{c}321.70 \pm 3.87 \\
\text { bcd }\end{array}$ & $\begin{array}{c}332.93 \pm 6.51 \\
d\end{array}$ & 16 days & $316.66 \pm 6.97$ & $295.58 \pm 3.75$ \\
\hline 96 hours & $343.50 \pm 5.94$ & $360.4] \pm 7.07$ & 32 days & $366.95 \pm 7.41$ & $315.55 \pm 3.65$ \\
\hline & & & 64 days & . & $385.65 \pm 3.92$ \\
\hline
\end{tabular}

Table (3): Changes in branchial $\mathrm{Na}^{+}-\mathrm{K}^{+}$- ATPase sctivity ( $\mu \mathrm{mol} \mathrm{Pj/mg} \mathrm{protein/hr)} \mathrm{of} \mathrm{grass}$ carp; Clenophargngodon idella, after lethal and subtethal exposure to mercury and zinc.

\begin{tabular}{|c|c|c|c|c|c|}
\hline \multicolumn{3}{|c|}{ Lethal exposure } & \multicolumn{3}{|c|}{ Sublethal exposure } \\
\hline Meta! & $\mathrm{Hg}$ & $2 n$ & Metal & $\mathrm{Hg}_{\mathrm{g}}$ & $\mathrm{Zn}$ \\
\hline $\begin{array}{l}\text { Conc. } \\
\text { Time }\end{array}$ & $0.62 \mathrm{mg} /$ & $11.46 \mathrm{mg} / \mathrm{l}$ & $\begin{array}{l}\text { Conc. } \\
\text { Time }\end{array}$ & $0.062 \mathrm{mg} / \mathrm{l}$ & $1.146 \mathrm{mg} / \mathrm{l}$ \\
\hline Contro! & $\begin{array}{c}5.22 \pm 0.09 \\
4\end{array}$ & $\begin{array}{c}5.14 \pm 0.10 \\
\mathrm{a}\end{array}$ & Control & $5.09 \pm 0.17$ & $\begin{array}{c}5.22 \pm 0.12 \\
\mathrm{a}\end{array}$ \\
\hline 3 hours & $\begin{array}{c}5.26 \pm 0.07 \\
s b\end{array}$ & $\begin{array}{c}5.09 \div 0.06 \\
a b\end{array}$ & 1 day & $\begin{array}{c}4.56 \pm 0.13 \\
\mathrm{a}\end{array}$ & $\begin{array}{c}5.39 \pm 0.04 \\
\mathrm{ab}\end{array}$ \\
\hline 6 hours & $\begin{array}{c}4.59 \pm 0.09 \\
c\end{array}$ & $\begin{array}{c}5.11 \pm 0.05 \\
\text { abc }\end{array}$ & 2 days & $\begin{array}{c}4.60 \pm 0.07 \\
\pm b\end{array}$ & $\begin{array}{c}5.46 \pm 0.03 \\
a b \\
\end{array}$ \\
\hline 12 hours & $\begin{array}{c}5.04 \pm 0.08 \\
\mathrm{ab}\end{array}$ & $\begin{array}{c}5.25 \pm 0.05 \\
\text { abed }\end{array}$ & 4 days & $\begin{array}{c}4.38 \pm 0.09 \\
a b c\end{array}$ & $\begin{array}{c}5.09 \pm 0.09 \\
\mathrm{abc}\end{array}$ \\
\hline 24 hours & $\begin{array}{c}4.28 \pm 0.12 \\
c\end{array}$ & $\begin{array}{l}5.16 \pm 0.12 \\
\text { abcde }\end{array}$ & 8 days & $\begin{array}{c}4.22 \pm 0.17 \\
\text { abad }\end{array}$ & $\begin{array}{c}5.0] \pm 0.12 \\
\mathrm{ac}\end{array}$ \\
\hline 48 hours & $\begin{array}{c}4.30 \pm 0.08 \\
\mathrm{~d}\end{array}$ & $\begin{array}{c}5.19 \pm 0.09 \\
\text { abedef }\end{array}$ & 16 days & $\begin{array}{l}3.99 \pm 0.16 \\
\text { cde }\end{array}$ & $\begin{array}{c}4.74 \pm 0.09 \\
d\end{array}$ \\
\hline 96 hours & $\begin{array}{c}4.21 \pm 0.05 \\
\mathrm{~d}\end{array}$ & $\begin{array}{l}5.11 \pm 0.11 \\
\text { abcdef }\end{array}$ & 32 days & $\begin{array}{c}3.90 \pm 0.14 \\
\mathrm{de}\end{array}$ & $\begin{array}{c}4.45 \pm 0.06 \\
d\end{array}$ \\
\hline & & & 64 days & - & $\begin{array}{c}4.28 \pm 0.05 \\
d\end{array}$ \\
\hline
\end{tabular}

- Data are represented as mean \pm SE.

- Means with the same letlers in the same column are not aignificantly different $(P>0.05) \quad$ Fish died. 


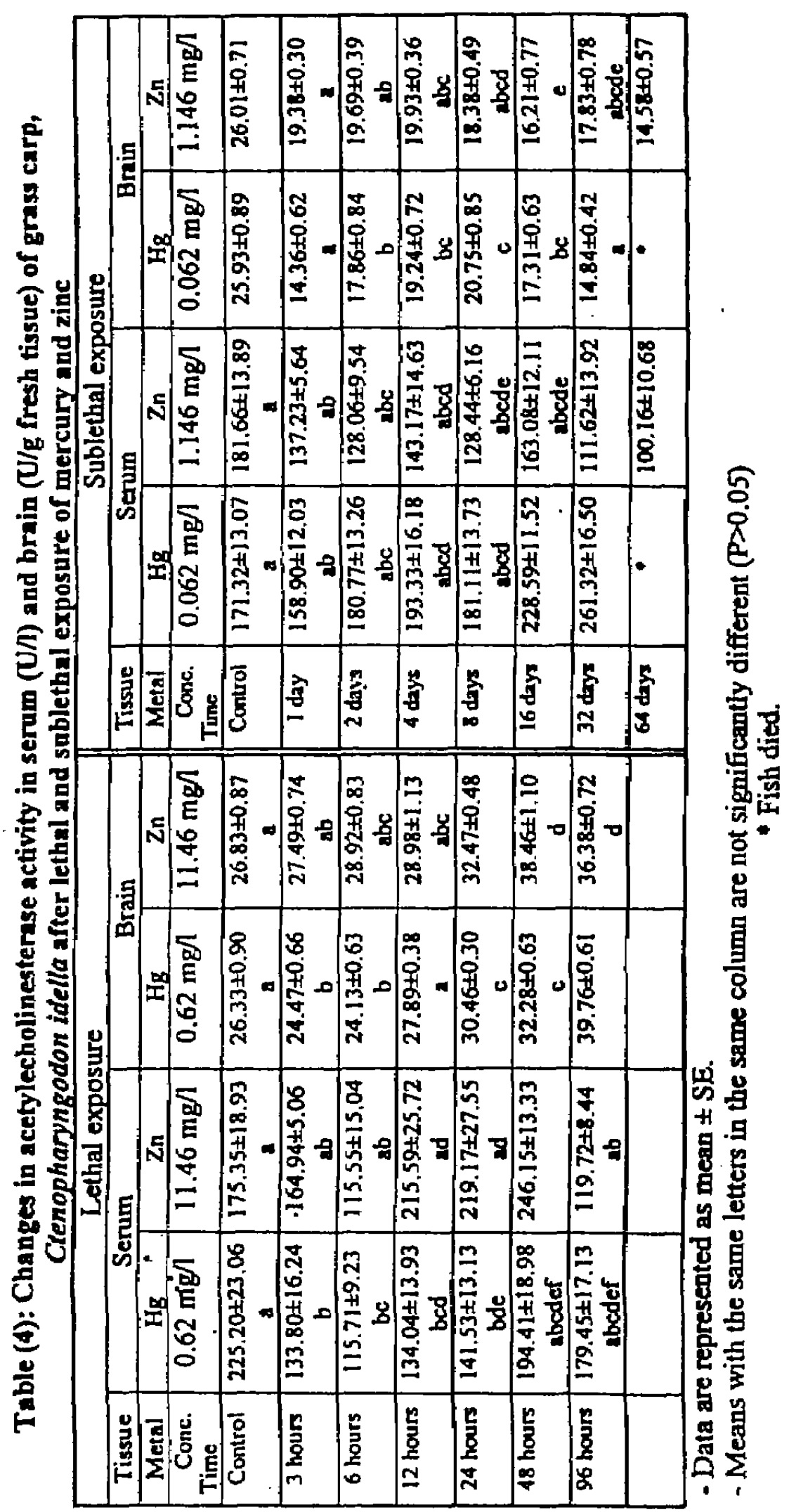




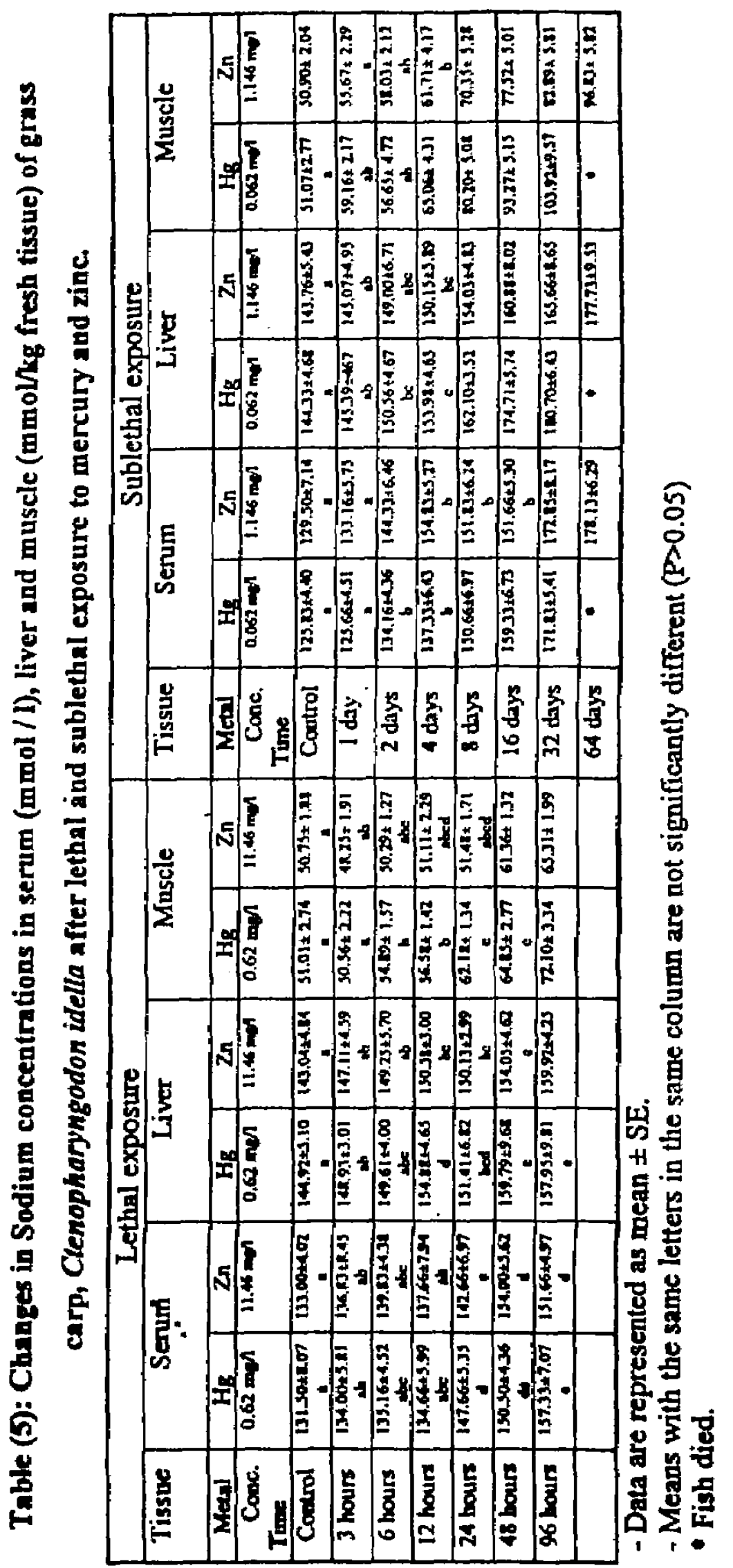




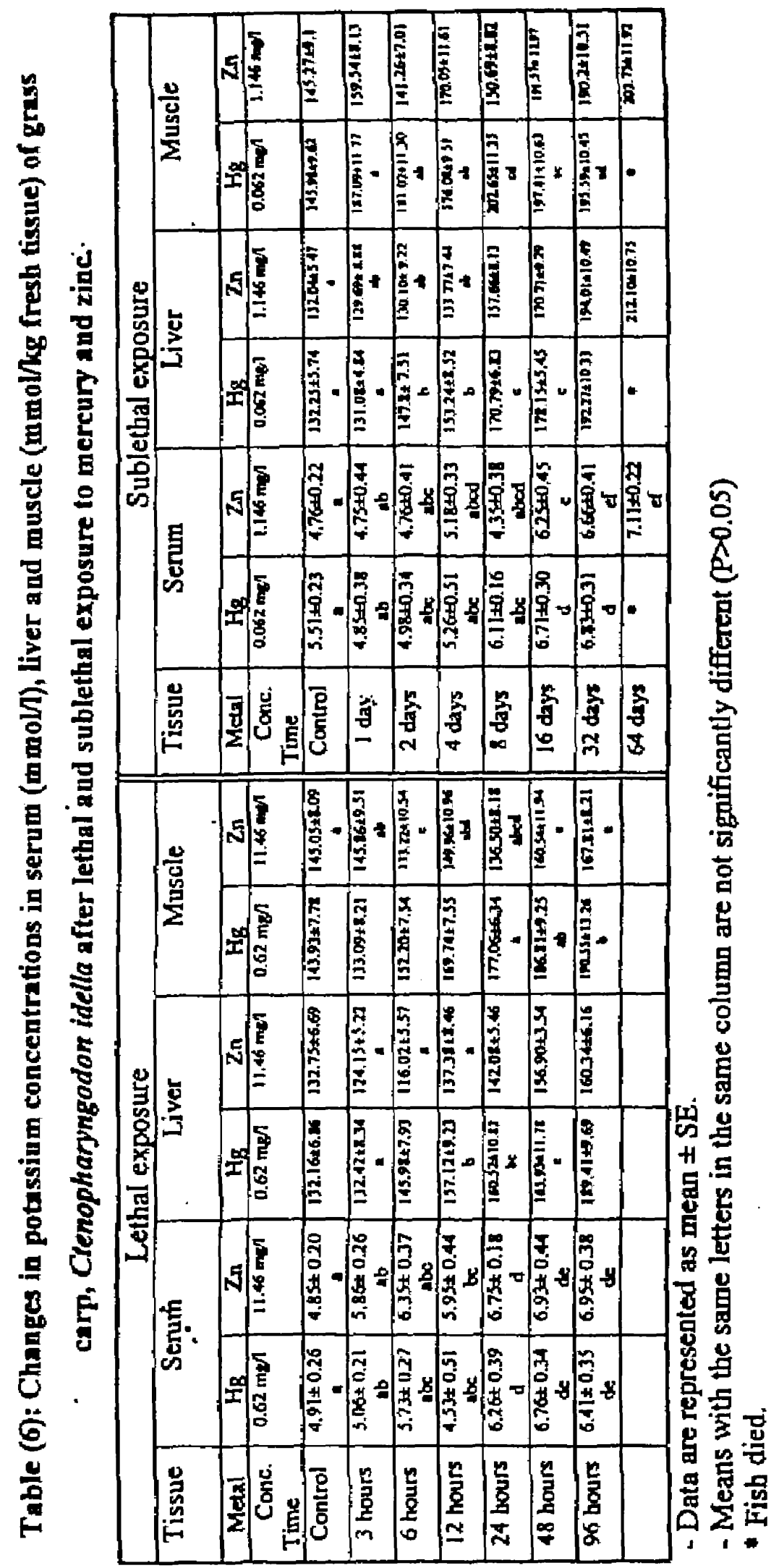




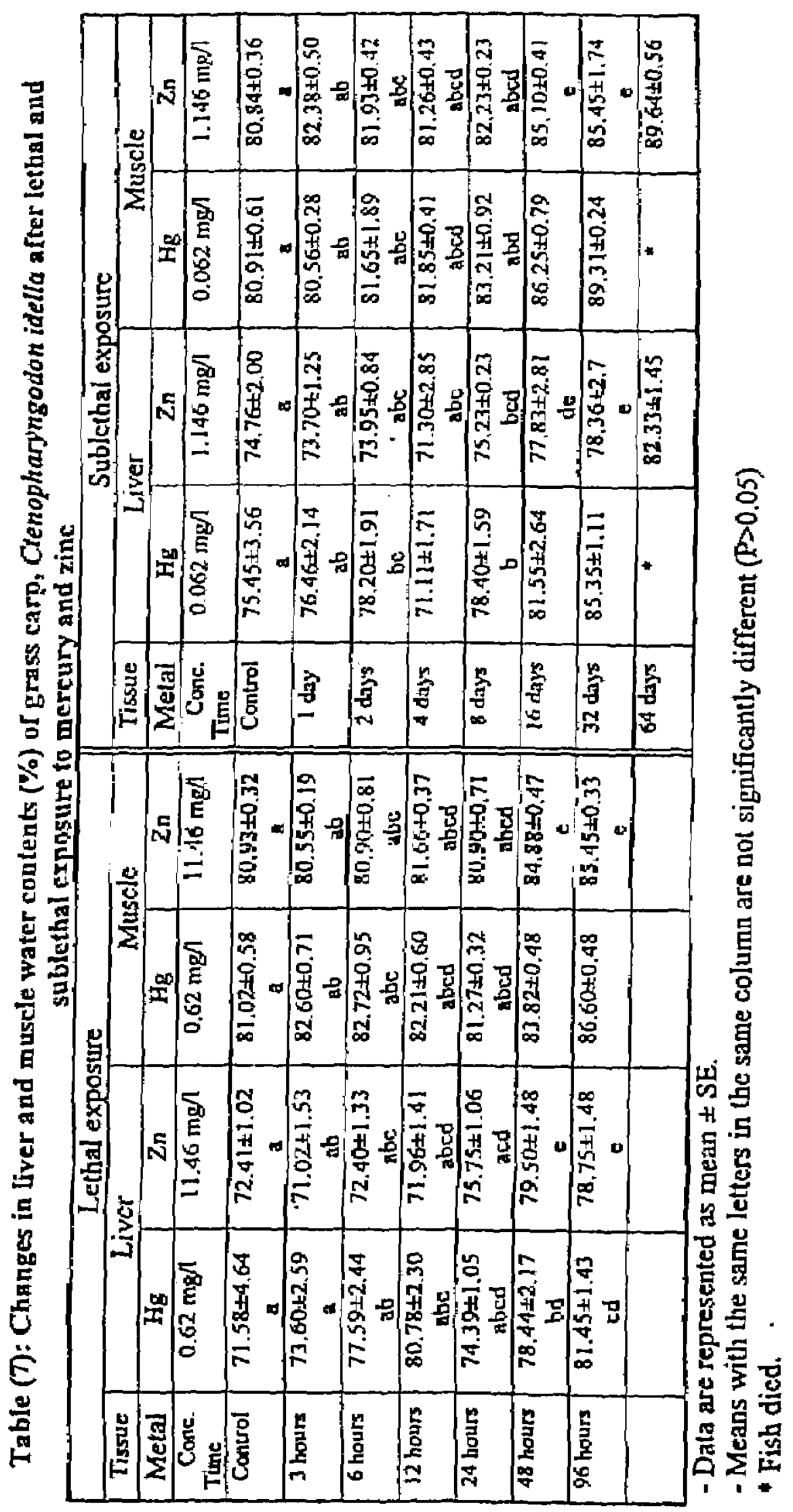

